\title{
PENANGANAN BENCANA GEMPA BUMI DI INDONESIA MASA KOLONIAL BELANDA
}

\author{
Earthquake Disaster Management in Indonesia during \\ The Dutch-Indie Colonial Age
}

Resa Tri Andani, Zukhrufa Ken Satya Dien

Universitas Negeri Yogyakarta

Jalan Colombo No.1, Karang Malang, Caturtunggal, Kec. Depok, Sleman

Daerah Istimewa Yogyakarta, 55281

Email: Resatri26@gmail.com, Kenufa.zukhrufa@gmail.com

\begin{abstract}
Indonesian territory has areas that are very vulnerable to natural disasters. Natural disasters that frequently occur in Indonesia are earthquakes. An earthquake occurs when various microsubcontinent plates and arcs of fire collide, which is driven by a complex tectonic process until it is in its current place. The plate collisions causing the formation of various types of faults that are scattered in various places, constantly receiving and accumulating tectonic forces from the interaction of lithosphere plate. The occurrence of earthquakes in the past can be taken as a lesson from the history useful insights to deal with a problem. This article discusses the worst earthquakes during the Dutch Indie colonial rule, the impacts, and how they overcame the disasters. Thus, we can learn and understand the history of earthquake disaster management during the Netherlands colonial rule in Indonesia.
\end{abstract}

Keywords: earthquake, Nederlands colonialism, disaster mitigation

\begin{abstract}
Abstrak
Wilayah Indonesia memiliki daerah yang sangat rentan terhadap bencana alam. Bencana alam yang sering terjadi di Indonesia adalah gempa bumi. Gempa bumi terjadi karena gabungan berbagai lempeng benua mikro dan busur api, yang digerakkan oleh proses tektonik yang kompleks hingga berada pada tempatnya saat ini. Proses tumbukan lempeng inilah yang menyebabkan terbentuknya berbagai jenis patahan yang tersebar di berbagai tempat, senantiasa menerima dan menimbun gaya tektonik dari interaksi lempeng litosfer. Terjadinya gempa bumi di masa lalu menjadi sebuah pembelajaran dari-sejarah yang dapat memberikan wawasan yang berguna untuk menghadapi sebuah masalah. Artikel ini membahas mengenai terjadinya gempa bumi terparah yang terjadi pada masa pemerintahan kolonial Hindia-Belanda, dampak yang terjadi,dan cara mereka dalam mengatasi bencana gempa bumi tersebut. Dengan demikian, kita dapat belajar dan mengerti sejarah penanganan sebuah bencana gempa bumi pada masa pemerintahan kolonial Hindia-Belanda di Indonesia.
\end{abstract}

Kata kunci: gempa bumi, kolonial Hindia-Belanda, mitigasi bencana

\section{PENDAHULUAN}

Wilayah Indonesia merupakan daerah yang sangat rentan terhadap bencana alam. Hal ini dikarenakan faktor geologis yang berada pada tiga lempeng litosferik besar yaitu Lempeng Eurasia, Lempeng Pasfik, dan Lempeng Indo-Australia yang menyebabkan 
gaya interaksi antar lempeng tersebut senantiasa menekan dan menggeser berbagai patahan yang tersebar di seluruh bagian Indonesia, baik daratan maupun di dasar laut. Selain itu ada faktor lainnya yaitu pada masa lampau selama puluhan juta tahun, wilayah ini dibangun atas gabungan berbagai lempeng benuai mikro dan busur api, yang digerakkan oleh proses tektonik yang kompleks hingga berada pada tempatnya saat ini. Peroses tumbukan lempeng inilah yang menyebabkan terbentuknya berbagai jenis patahan yang tersebar di berbagai tempat, senantiasa menerima dan menimbun gaya tektonik dari interaksi lempeng litosfer saat ini (Salahudin, 2016: 1)

Wilayah Indonesia juga disebut dengan wilayah the ring of fire atau cincin api. Daerah cincin api Pasifik berbentuk U atau tapal kuda dengan $40.000 \mathrm{~km}$. Letaknyya seringkali dikaitkan dengan palung samudra, sabuk vulkanik dan pergerakan lempeng kerak bumi yang letaknya berdekatan dan terjadi secara terus menerus. Di daerah cincin api ini terdapat 452 gunung berapi dan $75 \%$ gunung berapi aktif di dunia berada di wilayah ini. Hal ini mengakibatkan sering terjadinya letusan gunung berapi hingga gempa bumi. Sekitar 12 tempat di Indonesia termasuk Kawasan cincin api yaitu Gunung Tambora (Pulau Sumbawa,NTB), Toba - Sibayak - Sinabung - Tarutung (Sumatera Utara), Gunung Krakatau (Selat Sunda), Gunung Agung - Batur - Rinjani (Bali, Lombok), Gunung Semeru - Penanggungan - Bromo - Ijen - Kelud (Jawa Timur), Gunung Merapi - Merbabu - Lawu-Sindoro - Sumbing - Dieng (Jawa Tengah), Gunung Tangkuban Perahu - Salak-Papandayan - Galungagung (Jawa Barat), Gunung KerinciDempo-Sorik Merapi (Sumatera), Gunung Rokatenda - Egon - Lewo - Tobi - Ende Larantuka (NTT), Sangihe - Ambon - Ibu - Saputan (Kepulauan Ambon), Liwang Padang - Aceh - Palu (Sesar darat), Mentawai - Nias - Simeulue (Pulau di batas benua) (Tyanti, 2013: 26-29).

Sejarah mencatat bencana disebabkan oleh tiga fase penting yaitu act of god, act of nature, dan act of men and women. Sebagai contoh daerah Indonesia yang terjadi gempa bumi berada di wilayah Simeleu dan Aceh, Jawa, Sulawesi, sampai wilayah Papua. Dalam sejarah terdapat gempa yang dasyat di wilayah Indonesia pada abad ke-19 yaitu di daerah Padang, Yogyakarta, Maluku, dan lain-lain. Gempa yang terjadi membawa dampak pada berbagai sector kehidupan, mulai dari sosial, ekonomi, hingga politik. Sebelum datangnya pemerintah kolonial Hindia-Belanda pencatatan dan lembaga penangan bencana di Indonesia belum ada sehingga, pada masa tersebut dibentuklah sebuah bada pengawasan dan pengamatan di wilayah Hindia-Belanda untuk mencoba menanggulangi dampak yang dibawa oleh gempa tersebut. Lembaga ini mulai berdiri di paruh kedua abad ke-19. Tujuan utamanya ialah tidak hanya untuk kepentingan pemerintah kolonial, namun digunakan juga untuk perkembangan ilmu pengetahuan (Riskianingrum, 2013: 2-3).

Penelitian menggunakan pendekatan historis untuk menjelaskan dampak dan aspek penangan gempa pada masa pemerintahan kolonial Hindia-Belanda. Peristiwa yang diamati adalah peristiwa gempa di wilayah Maluku, di Padang dan di Jawa pada tahun 
1646 hingga 1899. Sumber penelitian terdiri atas arsip dan dokumen. Arsip diperoleh melalui Arsip Nasional Republik Indonesia (ANRI) dan BPAD Daerah Istimewa Yogyakarta. Selain itu dilakukan pula tinjauan pustaka atas penelitian yang pernah dilakukan sebelumnya. Sumber-sumber yang sudah terkumpul kemudian dianalisis secara deskriptif-eksplanatif untuk menjelaskan bagaimana dampak dari gempa dan upaya pembentukan lembaga untuk penanganan gempa pada masa pemerintahan kolonial Hindia-Belanda

\section{PEMBAHASAN}

\section{Terjadinya Gempa Masa Kolonial Di Indonesia}

Bencana gempa bumi yang sering melanda Indonesia masa pemerintahan kolonial Hindia-Belanda membuat para ilmuan Eropa berbondong-bondong meneliti mengenai kejadian gempa bumi yang kerap melanda Indonesia. Salah satunya Junghunhn yang sudah pernah menemukan awal bencana gempa bumi yang pernah terjadi di Indonesia. Sekitar tahun 1000 Junghunhn menemukan bahwa di wilayah Nusantara pernah terjadi gempa vulkanik yang sangat hebat dan menewaskan banyak korban jiwa (Junghuhn, 1845: 1381). Selain Junghunhn, masih banyak lagi ilmuwan Eropa yang melakukan penelitian di Nusantara.

Ketika Nusantara masih dijajah oleh pemerintah kolonial Hindia-Belanda banyak sekali bencana alam yang terjadi salah satunya gempa bumi. Banyaknya gempa bumi di Nusantara membuat pemerintah kolonial Hindia-Belanda melakukan pencatatan mengenai bencana yang terjadi di Nusantara saat itu. Dalam catatan sejarah di Maluku pernah terjadi gempa bumi sebanyak 10 kali dan mengakibatkan terjadinya tsunami, namun kemungkinan bisa lebih terjadinya gempa bumi di Maluku ketika masih dijajah oleh Belanda. Pertama kali terjadi gempa bumi di Maluku berada di Ambon pada 17 Februari 1674. Gempa bumi ini terjadi sepanjang malam diikuti dengan suara seperti tembakan meriam. Korban jiwa dari gempa bumi yang terjadi di Ambon mencapai 2.300 jiwa (Leirissa et al. 2004: 49-55). Selain bencana gempa bumi yang terjadi di Ambon tahun 1674, terdapat pula bencana gempa masif yang terjadi selama satu bulan lamanya.Gempa masif tersebut terjadi pada tanggal 18 Agustus 1754 hingga 11 September 1754 yang membuat kota Ambon rata dengan tanah (Gambar 1), temasuk di antaranya benteng Victoria.

Dua peristiwa gempa bumi yang terjadi di Ambon tersebut merupakan sebuah gambaran mengenai sebuah kejadian yang luar biasa di wilayah Maluku masa penjajahan Hindia-Belanda. Masih terdapat delapan catatan sejarah mengenai terjadinya gempa bumi di Maluku. Menurut hasil penelitian bahwa bencana gempa bumi yang paling parah berada di Pulau Seram yang tejadi pada 30 September 1899 yang disertai dengan tsunami dengan ketinggian gelombang sekitar 9 meter. Tiga wilayah di Pulau Seram yang disapu oleh tsunami pasca gempa yaitu Samasuru dan Poulohi yang selamat dari gempa bumi 
dan Tsunami berjumlah 170 orang saja, kemudian wilayah Hatusua merenggut nyawa 100 korban jiwa (Boelens, dkk., 2001: 26-31).

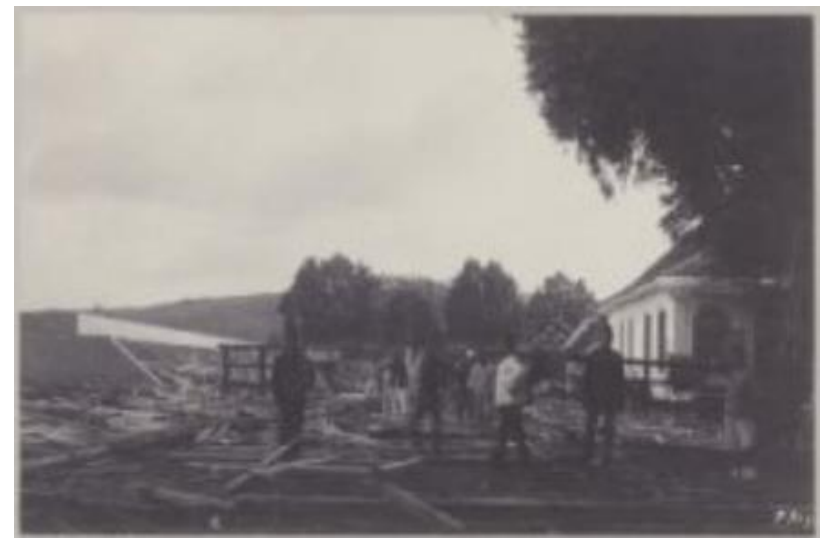

Gambar 1. Kerusakan akibat gempa bumi yang terjadi di Ambon tahun 1754 (Sumber: www.kitlv.nl, diunduh pada 30 September 2020)

Tabel 1. Catatan Bencana Gempa Bumi di Maluku

\begin{tabular}{|c|l|}
\hline 1674 & Gempa tektonik di Ambon \\
\hline $1646,1861,1890$ & Gempa vulkanik di Maluku Utara, disebabkan gunung Kie Besi \\
\hline 1659 & $\begin{array}{l}\text { Gempa vulkanik di Maluku Tenggara, disebabkan gunung } \\
\text { Furuweri }\end{array}$ \\
\hline 1693 & Gempa vulkanik di Maluku Tenggara tepatnya pada Pulau Serua \\
\hline 1754 & Gempa tektonik massif selama hampir 1 bulan \\
\hline 1775 & $\begin{array}{l}\text { Gempa vulkanik di Maluku Tenggara, disebabkan gunung } \\
\text { Gamalama }\end{array}$ \\
\hline 1841 & $\begin{array}{l}\text { Gempa tektonik di Naira, Banda yang menyebabkan terjadinya } \\
\text { Tsunami }\end{array}$ \\
\hline 1899 & Gempa tektonik di Pulau Seram yang menyebabkan Tsunami \\
\hline
\end{tabular}

Sumber: Marlon, 2014: 100-104

Bencana gempa bumi masa kolonial Hindia-Belanda di Maluku sudah menghancurkan serta menewaskan banyak korban jiwa. Selain di wilayah Maluku bencana gempa bumi terjadi di Padang pada tahun 1797 yang mengakibatkan terjadinya tsunami. Tsunami ini terjadi di Selat Mentawai dengan tinggi gelombang 30 meter dan menelan korban jiwa-sebanyak 300 orang dari 10.000 penduduk. Selain di Pulau Sumatera, bencana gempa bumi tertua pada masa pemerintahan kolonial Hindia-Belanda 
di Pulau Jawa yang tejadi pada tahun 1883. Gempa bumi yang terjadi di Pulau Jawa tersebut diakibatkan oleh meletusnya gunung Krakatau. Gempa vulkanik ini juga mengakibatkan terjadinya tsunami yang sangat besar. Menurut sejarah meletusnya gunung Krakatau ini menelan korban jiwa tebanyak yaitu sekitar 36.000 jiwa.

Pada masa pemerintahan kolonial Hindia-Belanda, bencana gempa bumi terjadi di 28 wilayah di Indonesia. Wilayah yang rawan gempa bumi antara lain di Nanggroe Aceh Darusalam, Sumatera Utara, Sumatera Barat, Bengkulu, Lampung, Banten, Jawa Tengah dan Daerah Istimewa Yogyakarta bagian selatan, Jawa Timur bagian selatan, Bali, Nusa Tenggara Barat dan Nusa Tenggara Timur, Sulawesi Utara, Sulawesi Tengah, Sulawesi Selatan, Maluku Utara, Maluku Selatan, Biak, Yapen dan Fak-Fak di Papua serta Balikpapan di Kalimantan Timur. Daerah yang aman dari bencana gempa bumi meliputi pantai timur Sumatera (Riau, sebagian Jambi, Sumatera Selatan), Laut Cina Selatan, Kalimantan dan Bagian utara Laut Jawa serta perairan Laut Arafuru sebelah Selatan Papua (Sudarani, 2013: 28).

\section{Dampak Gempa masa Kolonial Belanda di Indonesia}

Bencana Gempa bumi yang terjadi di Kawasan Hindia-Belanda sangat membawa dampak yang luar biasa di antaranya:

a. Terjadi Tsunami

Salah satu dampak dari gempa ialah terjadinya tsunami, tercatat beberapa kali Tsunami melanda wilayah Hindia-Belanda. Wilayah tersebut ialah tsunami yang terjadi di Padang pada tahun 1797 yang mengakibatkan seluruh kota terendam tsunami, beberapa rumah dilaporkan hanyut terbawa gelombang. Kemudian pada tahun 1833, Tsunami besar yang dibangkitkan oleh gempa merusak banyak lokasi di wilayah Bengkulu, Pulau Cinco, Indrapura, Padang, dan Pariaman (Surjo, dkk.,2016: 51). Selain di daerah Sumtera, tsunami akibat gempa juga terjadi di Kepulauan Banda pada tahun 1852. Kala itu terjadi tsunami beruntun sebanyak 26 kali dengan tinggi mencapai hinggi hampir 4 meter. Tsunami juga terjadi setelah gempa pada tanggal 30 September 1899 di Hatusua, kepulauan Maluku SDA (Marlon, 2014: 102-104). 


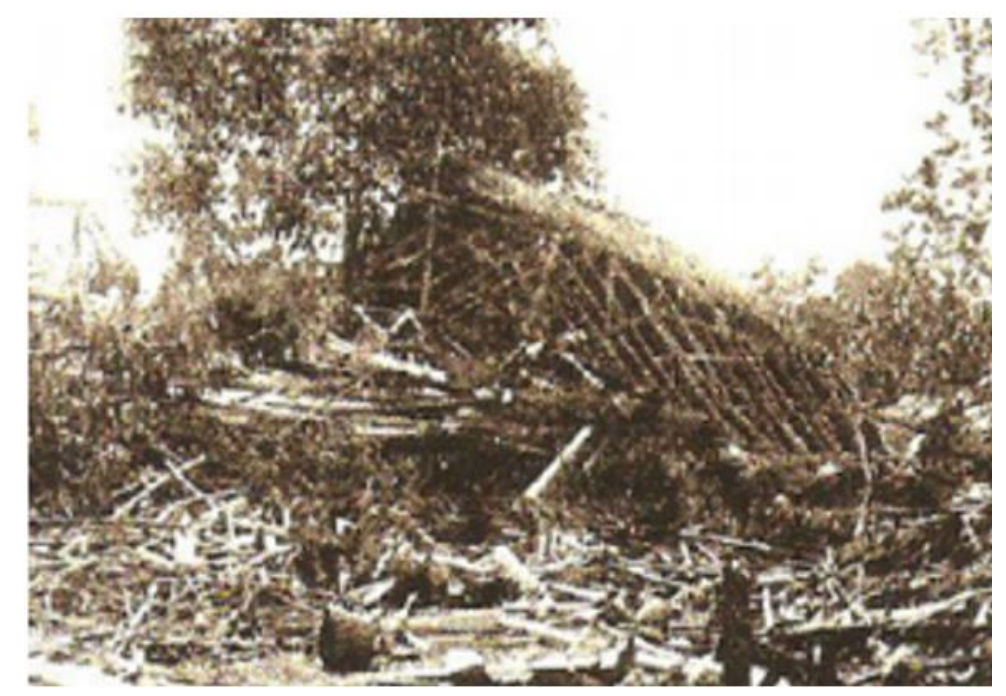

Gambar 2. Kehancuran di wilayah Hatusua pasca Tsunami setelah peristiwa gempa tanggal 30 September 1899 (Sumber: Boelens dalam Marlon, 2014: 104)

\section{b. Dampak Sosial, Ekonomi, Politik}

Gempa bumi yang terjadi di kawasan Hindia-Belanda juga membawa dampak di bidang social ekonomi, dan politik. Dalam bidang sosial gempa bumi membawa dampak yaitu banyaknya korban meninggal. Tercatat dalam gempa bumi yang terjadi di Padang pada tahun 1997 ada 300 orang meninggal. Kemudian di Pulau Nias hanya ada 170 orang yang selamat dari 1.700 orang, serta gempa dan tsunami di Pulau Nias mengakibatkan 3.500 orang meninggal (Marlon, 2014:100-105). Hingga pada tahun 1926 gempa yang terjadi di Padang menelan 354 korban jiwa. Hal ini mengakibatkan meningkatnya rasa empati dari masyarakat luas untuk memberikan bantuan kepada korban bencana. Hal ini dapat dilihat dari masyarakat melakukan inisiatifuntuk terlibat dalam penanganan dengan beragam cara dan berbasis kelompok, etnis, dan organisasi. Smeroe Fonds merupakan sebuah yayasan kemanusiaan yang didirikan pada 15 April 1910 yang khusus menolong korban bencana alam (Yose, 2017: 25).

Ekonomi dan politik masa Kolonial juga terhambat karena dampak gempa yang terjadi karena hampir semua infrastruktur dan gedung pemerintahan rusak parah. Tercatat dalam gempa 1833 di Padang banyak bangunan, benteng, hingga menara mengalami kerusakan yang parah hingga tidak bisa digunakan lagi. Para nelayan juga tidak bisa berlayar karena selain kapal mereka hancur, dermaga yang ada juga mengalami kerusakan akibat gempa. Selain itu dampak gempa ini juga sampai di Bengkulu yang menyebabkan runtuhnya dam alam sehingga menyebabkan banjir di lereng lembah,dan mengakibatkan satu kampung tenggelam (Surjo, dkk., 2016:50-24). Selain itu gempa di Nias pada tahun 1852 menyebabkan Benteng Belanda di Lagundri mengalami kerusakan parah karena 
gempa dan tsunami. Perlengkapan militer yang ada di dalam benteng tenggelam dan tidak berfungsi lagi (Anatona, dkk., 2018: 33). Ekonomi dan politik di Padang juga sempat hancur karena gempa yang tejadi pada tahun 1926, hal ini dikarenakan menghancurkan rumah dan gedung, merusak infrastruktur seperti jalur kereta api yang menjadi akses utama penghubung berbagai kota di Sumatera Barat (Yose, 2017: 3).

\section{Mitigasi Bencana yang dilakukan Pemerintah Kolonial Belanda}

Pada gempa di Padang tahun 1926 pemerintah Hindia-Belanda yang ada di Padang mengirim telegram untuk meminta bantuan ke pemerintah pusat di Bogor. Kemudian pada 3 Juli 1926 pemerintah pusat mengirimkan bantuan yaitu mengirimkan militer untuk membantu korban selamat serta mengamankan keadaan yang ada. Selain itu pemerintah Belanda mengirimkan seorang ahli vulkanologi untuk memeriksa penyebab gempa tersebut. Hal ini dikarenakan ada dugaan gempa tersebut terjadi akibat aktivitas Gunung Talang. Namun dugaan ini salah karena gempa terjadi karena aktivitas tektonik moderated segmen sesar Sumatera. Kemudian untuk menindaklanjuti penanganan dampak gempa ini, maka pemerintah Hindia-Belanda melakukan rehabilitasi kota dengan cara membangun kembali rumah dan fasilitas umum seperti kantor pemerintahan, pasar, hingga jalur kereta api. Selain dari pemerintah, pihak swasta juga turut membantu menangani masalah gempa di Padang di antaranya Smoeroe Fonds, Javaanshe Bank, Studiefonds Kota Gedang Tjabang Betawi, hingga bantuan 1 Juta Pounds dari Sydney (Riskianingrum, 2013: 4-5).

Sejak abad ke-18, Pemerintah Hindia-Belanda telah membangun lembaga penelitian ilmu pengetahuan, yang salah satu tujuannya ialah meminimalisir dampak dari bencana yang terjadi. Lembaga Ilmu pengetahuan yang dibangun ialah De Bataviaasch Genootschap van Kunsten en Wetenschappen BG biasa dikenal dengan di Batavia. Lembaga ini memfokuskan penelitian pada ilmu pengetahuan dan seni kebudayaan di tanah jajahan sebagai bentuk informasi bagi pemerintah. Seiring berkembangnya ilmu pengetahuan maka pada tanggal 1 Januari 1866 dibentuklah Koninklijk Magnetisch en Meteorologisch Observatorium te Batavia (KMMO). Sejak saat itu pengukuran temperatur, tekanan atmosfir, kecepatan arah angin, durasi dan intensitas matahari, serta curah hujan diamati di observatorium ini. Selanjutnya pada tahun 1867, Bergsma meluaskan penelitiannya dengan meneliti medan magnet untuk mengetahui komposisi struktur bumi, pengamatan seismologi untuk mengetahui kandungan material bumi dari getarannya, dan pengamatan seismograf atau pencatatan getaran bumi untuk mengetahui sumber getaran. Namun, baru pada 1898 observatorium baru menggunakan alat microseismic dan photographic seismograph, sebuah alat untuk mendeteksi gelombang dan getaran lapisan bumi. Pengamatan mengenai gempa bumi baru dilakukan pada tahun 1908 dengan pemasangan komponen horizontal seismograf Wiechert di Jakarta, sedangkan pemasangan komponen vertical dilaksanakan pada tahun 1928. 
Pada tahun 1907, pemerintah kolonial juga berusaha memasang alat tersebut di Ambon dan Padang, namun alat tersebut tidak berfungsi dengan baik karena hal tersebut maka alat tersebut dipindahkan kembali ke Batavia. Pada tahun 1912 dilakukan reorganisasi pengamatan meteorologi dengan menambah jaringan sekunder. Lebih lanjut, jasa meteorologi mulai digunakan untuk penerangan pada tahun 1930. Lembaga ini yang nantinya dinasionalisai dari Jawatan Meteorologisch en Geofisiche Dienst menjadi Jawatan Meteorologi dan Geofisika di bawah koordinasi Departemen Perhubungan dan Pekerjaan Umum. Pada saat ini Lembaga ini berganti menjadi Badan Meteorologi, Klimatologi, dan Geofisika (BMKG) yang bertugas mengawasi cuaca, iklim, serta gempa (Riskianingrum, 2013: 8-11).

\section{SIMPULAN}

Wilayah Indonesia memiliki daerah yang sangat rentan terhadap bencana alam. Hal ini dikarenakan faktor geologis. Ketika Nusantara masih dijajah oleh pemerintah kolonial Hindia-Belanda banyak sekali bencana alam salah satunya gempa bumi. Banyaknya gempa bumi di Nusantara membuat pemerintah kolonial Hindia-Belanda melakukan pencatatan mengenai bencana yang terjadi di Nusantara saat itu. Wilayah yang rawan gempa bumi antara lain di Nanggroe Aceh Darusalam, Sumatera Utara, Sumatera Barat, Bengkulu, Lampung, Banten, Jawa Tengah dan Daerah Istimewa Yogyakarta bagian Selatan, Jawa Timur bagian selatan, Bali, Nusa Tenggara Barat dan Nusa Tenggara Timur, Sulawesi Utara, Sulawesi Tengah, Sulawesi Selatan, Maluku Utara, Maluku Selatan, Biak, Yapen dan Fak-Fak di Papua serta Balikpapan di Kalimantan Timur. Dampak dari gempa yang terjadi di antaranya dampak dalam bidang sosial yaitu banyaknya korban jiwa dan semakin kuatnya empati masyarakat yang tidak terkena gempa. Gempa bumi juga membawa dampak bagi sektor ekonomi dan politik. Dalam sektor tersebut terjadi kemandegan karena rusaknya infrastruktur umum hingga terputusnya jaringan komunikasi. Ada beberapa tindakan yang dilakukan oleh pemerintah kolonial diantaranya mengirim bantuan militer, memperbaiki infrastruktur umum, hingga mendirikan lembaga khusus untuk meneliti mengenai bencana yang terjadi di Kawasan Hindia-Belanda. 


\section{DAFTAR PUSTAKA}

“ALGENMENE SECRETARIE 1890-1941.” ANRI, t.thn.

Boelens,G. (2001). Natur en samenleving van de Molukken. Utrecht: Landelijk Steunpunt Educatie Molukkers.

Surjo, Djoko, dkk. (2016). Sejarah Bencana Gempa di Sumatera. Jakarta: Direktorat Sejarah Kementrian Pendidikan dan Kebudayaan RI.

Junghuhn,F. (1845). "Chronologisch overzigt der aandbevingen en uitbarstingen van vulkanen in Neerland Indie." Tijdschift Voor Nederlandsch-Indie Vol 7, No 1.

Husein, Salahudin. (2016). "Bencana." DPR Action Plan Workshop: Strengthened Indonesian Resilience : Reducing Risk from Disasters. 1.

KITLV: Royal Netherlands Institute of Southeast Asian and Caribbean Studies. Diakses November 14, 2020. www.kitlv.nl.

Leirissa, dkk. (2004). Ambonku: doloe, kini dan esok. Ambon: Pemerintah Kota Ambon.

Marlon. (2014). "Bencana Masa Lalu di Kepulauan Maluku: Pengetahuan dan Pengembangan bagi Studi Arkeologi.” AMERTA Vol 32, No 2

Ramadhani, Ana. (2018). "dari Mitos Hingga Realitas: Sejarah Gempa Bumi dan Tsunami di Pulau Nias." Prosiding Seminar Nasional 90 tahun Sumpah Pemuda (1928-2018.

Rizkianingrum, Devi. (2013). "Penanganan Bencana dan Transformasi Pengetahuan Tentang Kegempaan di Masa Kolonial." Paramita Vol 23, No 1.

Sudarani, Tyanti. (2013). “Gempa Bumi di Negara Cincin Api.” Majalah Arsip Edisi 60 26-29.

\section{HASIL DISKUSI}

Pertanyaan

1. Apakah Belanda pernah melakukan penelitian terhadap naskah-naskah tradisi yang terkait dengan bencana? Apakah di masa lalu (dalam konteks masa Hindia-Belanda) ada komunitas terkenal yang menuliskan berita tentang kebencanaan?

\section{Jawaban}

1. Menurut penulis, catatan mengenai sejarah kebencanaan yang disimpan oleh pemerintah kolonial di antaranya adalah babad jawa yang disimpan di keraton serta dokumen-dokumen seperti surat perintah, klipping berita mengenai terjadinya erupsi 
Gunung Merapi, serta dokumentasi mengenai tradisi masyarakat seperti mengirimkan sesajen ke Gunung Merapi yang disimpan di Museum Kearsipan Sonobudoyo Yogyakarta, Badan Arsip dan Perpustakaan Daerah Istimewa Yogyakarta dan arsip statis yang berada di Arsip Nasional Republik Indonesia. Terkait dengan komunitas, penulis belum mengetahui tentang hal tersebut, hal ini jarang sekali ada komunitas yang menuliskan berita kebencanaan. 